ancient times to the present. Coll. documents and materials. Kyiv-Chernivtsi: Knyhy- XXI, 507594 [in Ukrainian].

11. Siropolko, S. (2001). Istoriia osvity v Ukraini [History of education in Ukraine]. Kyiv: Nauk. dumka [in Ukrainian].

12. Skoropadskyi, P. (1995). Spohady. Kinets 1917-hruden 1918 [Memories. End 1917December 1918]. Kyiv-Filadelfiia [in Ukrainian].

13. Soldatenko, V. (2007). Revoliutsiini protsesy v Ukraini pislia povalennia samoderzhavstva [Revolutionary processes in Ukraine after the overthrow of the autocracy]. Ukraina: politychna istoriia. XX - pochatok XXI st. - Ukraine: political history. XX - beginning of XXI century. Kyiv: Parlamentske vyd-vo [in Ukrainian].

14. Tryhubenko, V. \& Kucher, T. (1996). Prosvitytel, derzhavnyi diiach [Enlightener, statesman]. Svitlo - Light, 2, 62-66 [in Ukrainian].

15. Chernov, B.O. (1995). Problemy rozvytku natsionalnoi osvity v Ukraini: 1917-1920 rr. [Problems of development of national education in Ukraine: 1917-1920]. Rozvytok osvity $v$ Ukraini (II pol. XIX - poch. XX st.) - Development of education in Ukraine (2nd half XIX - early $X X$ centuries). Kyiv: Instytut pedahohiky APN Ukrainy, 99-107 [in Ukrainian].

Одержано 18.04.2019.

УДК 94(477) «193»:17.022.1:168.35 DOI https://doi.org/10.31470/2415-35672019-46-75-85

Тарапон Оксана, кандидат історичних наук, доцент,

\section{Tarapon Oksana,}

Candidate of History, assistant professor of the Department of History and Culture of Ukraine oksanat@ukr.net https://orcid.org/0000-0003-2947-3816 Pereiaslav-Khmelnytskyi Hryhorii Skovoroda State Pedagogical University, 30, Sukhomlynsky Str., Pereiaslav-Khmelnytskyi, Kyiv region, Ukraine, 08401

\title{
МОНУМЕНТАЛІЗАЦІЯ ПОСТАТІ Т. ШЕВЧЕНКА В РАДЯНСЫКІЙ УКРАЇНІ 1930-Х РР.: ПІДМІНА НАЦІОНАЛЬНИХ ЦІННОСТЕЙ
}

У статті простежено прочес увіковічення радянською владою постаті T. Шевченка у 1930-хрр. через зведення монументальних пам'ятників Кобзарю, підкреслено неоднозначний характер офічійних заходів влади. У 1930-х рр. почалося масове знищення радянськими органами української культури, зазнають руйнування, перебувають у занедбаному стані пам'ятні місия, могили відомих українських діячів, у тому числі $і$ T. Шевченка. У ией же час почалася робота зі зведення грандіозних пам'ятних скульптур радянської пропаганди. Влада почала популяризувати окремі культурні об'єкти та постаті України, котрі мали презентувати велич багатонаціональної культури СРСР, серед яких був і Тарас Шевченко. Оскільки «вбити» пам'ять про Шевченка радянській системі було не під силу, почалося привласнення його 
образу, спадщини, розгорнувся довготривалий процес «радянізації» та більщовицької сакралізації образу Кобзаря.

До 20-ї річниці Жовтневої револючії влада звернула увагу на проблему реставрачії могили Тараса Шевченка, почався прочес зведення пам'ятників Кобзарю у Харкові та Києві. Крім художніх діячів до иієї роботи були залучені найвищі посадовці держави, котрі визначали не лише розміри кошторису, темпи $i$ засоби будівництва, а мали переважний голос при визначенні художньо-естетичного $i$, особливо, ідеологічного наповнення монументу. Як наслідок, образ Т. Шевченка втрачав начіональні ознаки та набував пролетарсько-революиійних рис. Крім того, розмахом будівництва $і$ величчю вшанування пам'яті про Шевченка влада намагалася послабити стан шоку власних громадян від масштабів руйнування культурних цінностей, звинувачення в тотальному знищенні національних святинь.

Ключові слова: Т. Шевченко, пам'ятник, наџіональні цуінності, радянська ідеологія.

\section{MONUMENTALIZATION OF T. SHEVCHENKO'S PERSONALITY IN SOVIET UKRAINE OF THE 1930's: REPLACEMENT OF NATIONAL VALUES}

The article traced how the Soviet authorities perpetuated the personality of T. Shevchenko in the 1930's, erected monumental monuments of Kobzar, and at the same time observed the ambiguous nature of official measures taken by the authorities. In the 1930's the mass destruction of the Soviet bodies of Ukrainian culture took place, they were destroyed, the memorial sites, the graves of famous Ukrainian figures, including Taras Shevchenko, were neglected. At the same time, work began to erect grandiose memorial sculptures of Soviet propaganda. Authorities began to promote individual cultural sites and personalitys of Ukraine, which were supposed to represent the majesty of the multinational culture of the USSR, including Taras Shevchenko. Since the Soviet system could not «kill» the memory of Shevchenko, the appropriation of his image, inheritance began, a long-term process of «Sovietization» and the Bolshevik sacralization of the image of Kobzar began.

By the 20th anniversary of the October Revolution, authorities began restoring and abandoned the Taras Shevchenko tomb, and began erecting Kobzar monuments in Kharkiv and Kiev. In addition to artistic figures, the highest officials of the state were involved in this work, who determined not only the size of the budget, the pace and the means of construction, but had a predominant voice in determining the artistic and aesthetic and, in especially, the ideological content of the monument. As a result, T. Shevchenko's image lost national character and became proletarian-revolutionary. In addition, with the scale of construction and the grandeur of the memory of Shevchenko, the authorities tried to alleviate the state of shock of their citizens on the scale of destruction of cultural values, accusations of the total destruction of national shrines.

Key words: T. Shevchenko, monument, national values, Soviet ideology.

3 одного боку, для більшовицьких діячів характерне глибоко нігілістичне чи вороже ставлення до проявів національно-культурного життя українців, прагнення знищити культурну спадщину України, 3 другого, - в процесі денаціоналізації і радянізації населення влада використовувала національні символи, надаючи їм радянського, інтернаціонального характеру, нівелюючи, тим самим, національні ознаки та смисли. У даному контексті проблема монументалізації постаті Тараса Шевченка в Радянській Україні 1930-х рр. ще не була висвітлена.

Нігілізм радянської влади до історичної пам'яті народів СРСР та до їх культурних цінностей загально відомий. Загалом створення як музеїв, так і монументальних об'єктів мало виконувати, в першу чергу, пропагандистське значення. Ідеологічна роль подібної діяльності полягала в кількох аспектах: безпосередня агітація і пропаганда через твори мистецтва; показ турботи радянської влади про духовні цінності народів СРСР; втілення 
грандіозних культурно-монументальних проектів для приголомшливого враження як на власних громадян, так і закордонну громадськість (гігантоманія).

Показовим прикладом в цьому сенсі може бути ситуація з ідеєю створення в Харкові Національного музею загальнореспубліканського характеру, що в 1928 р. зумовило громадський резонанс та інтерес іноземців. За офіційними повідомленнями задля реалізації цього задуму 3 різних міст України планувалося зібрати певну кількість музейних цінностей, книг і рукописів, оскільки в Харкові ні музею, ні пристойної бібліотеки не існувало. Представники Наркомосу звернулися до професури, причетної до музейних закладів i книгосховищ (зокрема м. Одеси) 3 проханням скласти список найбільш цінних речей для укладення каталогу цінностей, що має вийти друком. Науковці добросовісно склали списки абсолютно всіх наявних цінностей і стародруків (у т.ч. краєзнавчого характеру), аби представити до друку найбільш повний варіант регіональних історичних пам'яток. Після цього поступила вимога «вислати в двотижневий термін всі предмети, включені в списки». Такий поворот подій поставив під загрозу знищення майже всіх одеських музеїв у сенсі тої багаторічної роботи, яка в них велася і тої ролі, яку вони відігравали в культурному житті регіону. Музейні працівники забили тривогу з приводу того, що «розоряються показові найбільші бібліотеки, світового значення археологічний музей» тощо. І це при тому, що Харків не мав на той час жодної бази для музейної роботи. Діяльність Наркомосу викликала крайню стурбованість української професури, зумовила міжнародний резонанс, навіть поширення чуток на рівні дипломатичних консульств в УСРР щодо підготовки до евакуації Правобережної України та Одеси. Саме небажаність подібного резонансу, поширення чуток і негативна реакція робітничих мас викликала стурбованість на рівні Наркомосу закордонних справ [6, арк.56-58].

Дана ситуація свідчить про перевагу політичних та ідейних чинників над культурною доцільністю в діяльності керівних структур радянської держави. Тут простежується i прагнення до централізації духовних цінностей, i розмахи новостворюваних об'єктів культури, і абсолютна бездумність про можливі негативні наслідки нововведень. Показово, що абсолютно правильно оцінюючи культурну шкоду даного рішення, представник НКЗС більше акцентував увагу на шкідливих політичних наслідках даного вчинку.

Стосовно національних цінностей і символів підкорених Росією народів, було взято курс на визнання і популяризацію окремих культурних об'єктів та постатей України, котрі мали презентувати велич багатонаціональної культури СРСР. Серед знакових постатей українського народу був, звісно, Тарас Шевченко. Погодимося із твердженням І.Демуз, що культ Т. Шевченка, названий «національно-консолідуючим міфом», приваблював багатьох інтелектуалів, політичних та громадських діячів початку XX ст., набув згодом всеукраїнського, національного характеру та мав не лише сакральний зміст, а й об’єднуючу ідею єдиної, соборної України» [1, с.52]. Оскільки «вбити» пам'ять про Шевченка радянській системі було не під силу, почалося привласнення його образу, спадщини, розгорнувся довготривалий процес «радянізації» та більшовицької сакралізації образу Кобзаря.

Про нігілістичне ставлення парторганів до Шевченка свідчить хоч би той факт, що зі створенням грандіозних пам'ятних скульптур на честь Кобзаря паралельно спостерігалося злочинно байдуже ставлення до його творчості. Так, за розпорядженням секретаря обласного парткомітету КП(б)У Прядченко в Харкові 1936 р. галерею картин Шевченка почали «викидати» 3 приміщення, двірники міськради вдиралися в приміщення, ламаючи замки. Щоб зупинити цей вандалізм представникам галереї довелося звертатися безпосередньо до секретаря ЦК КП(б)У Попова [8, арк.71-72].

Завдяки масштабному процесу радянської «сакралізації» пам'яті Шевченка, вище партійне керівництво звернуло увагу на місця перебування поета, зокрема будинок у м. Яготин. За дорученням секретаря ЦК КП(б)У М.М. Попова представники від культури, члени КП(б)У А. Сенченко та І. Кириленко 1936 р. доповідали, що будинок міститься в 
колишньому маєтку князів Рєпніних в розкішному парку, що належить нині буряковому радгоспу ім. Ілліча. Якщо кілька княжих будинків використано під лікарню та гуртожиток робітників радгоспу, то флігель, де жив Шевченко, стоїть напівзруйнований і продовжує руйнуватися. Між тим на стінах будинку збереглися малюнки Шевченка. «Всі стіни будинку 3 середини і зовні вкрито численними написами відвідувачів, робітників цукроварні, колгоспників, студентів. Багато написів у віршованій формі. Цікаво те, що зустрічаються написи німецькою і єврейською мовами» [8, арк.53], - підкреслювали партдіячі від культури, констатуючи, що всі написи свідчать про «велику пошану і любов до Тараса» трудящих, хоч $\epsilon$ «кілька написів націоналістичного характеру». Із цього робився логічний висновок про потребу реставрації будинку і створення там культурного закладу: бібліотеки, читальні 3 шевченківською кімнатою або будинку творчості письменників [8, арк.53]. У даній доповідній піднімалося актуальне питання занедбаності інших пам'ятних місць української і російської культури, зокрема: занедбано будинок Керн в Лубнах, де двічі бував Пушкін; майже зрівняна з землею могила Лесі Українки в Києві; занедбана могила Квітки-Основ'яненка в Харкові; підлягає «ліквідації» могила Панаса Мирного в Полтаві. При цьому уривки з творів Л.Українки і П. Мирного увійшли в шкільні підручники, їх вивчає молодь, тому доцільність приведення до ладу їх могил очевидна. Облаштування цих об'єктів не передбачало великих коштів, але на думку доповідачів «матиме велике культурно-політичне значення» [8, арк.53].

Ситуація ця доволі показова - країна гучно готується до святкування 20-ї річниці Жовтня, а тоталітарна машина в руйнівному апогеї доводить до знищення національні цінності українців. 3 одного боку, вкладалися колосальні кошти в спорудження радянських об'єктів - пам'ятників радянської пропаганди, 3 другого, - нехтувалися справжні духовні цінності нації. Загальновідома висока поховально-поминальна культура українців зобов'язувала нащадків (та й громаду загалом) утримувати в належному порядку могили, дбати про їх зовнішній вигляд, порушення чого вважалося провиною перед померлим, засуджувалося людьми [3]. Ситуація кардинально змінилася в постгеноцидній Україні. Радянське керівництво нігілістично ставилося до об'єктів поховальної культури українців. Так, 1935 р., у зв’язку з перетворенням багатьох київських пагорбів на зони відпочинку, було знесено більшу частину кладовища на горі Щекавиця в Києві, заснованого ще 1772 р. [11].

Формується дозволений владою список класиків української культури, які мали презентувати духовну спадщину України у великій «сім'ї радянських народів». Одночасно занепадають їх могили, руйнуються національні місця пам'яті, котрі встояли навіть в лихі часи імперської неволі. Українське населення, знекровлене Геноцидом 1932-1933 pp. i залякане масовим терором, перестало дбати про пам'ять небіжчиків, занепадають кладовища, тотально руйнується традиційна обрядова культура. О. Довженко в 1944 р. iз сумом констатував ганебний стан кладовищ в Україні, як ознаку недбальства і морального занепаду. А з приводу стурбованості наркомів занедбаністю кладовищ митець влучно відмічав: «Навчіть поважати, шанувати і любити людську особистість, виховайте у молодих повагу до старших, хоча б до батьків, і кладовища самі прикрасяться. Повага до пам'яті, а не звільнення житлової площі» [2, с.56].

У зв'язку з 20-ю річницею Жовтня, влада звернула увагу на проблему реставрації могили Тараса Шевченка та зведення на тому місці пам'ятного знаку. 3-4 квітня 1937 р. могилу поета біля Канева відвідав начальник українського управління в справах мистецтв при РНК УРСР А. Хвиля разом з кількома представниками художньої інтелігенції. Наслідки огляду могили і місця для будівництва обеліску, разом 3 фінансовими та технічними розрахунками, він викладав у доповідній записці секретарю ЦК КП(б)У С.В. Косіору, прохаючи схвалити проект забудови, відкриття якої планувалося на квітень 1939 р. [9, арк.43]. Комісія по обстеженню могили Т. Шевченка в складі А. Хвилі та ще 11 осіб представників культури, мистецтва i будівництва постановила на могилі Т.Г. Шевченка збудувати пам'ятник за проектом 1-ї Української бригади скульпторів 
К.П. Бульдіна, А.І. Драгана і Я.С. Ражби; при спорудженні фундаменту під пам'ятник зберегти в повній недоторканості труну, для чого слід було визначити місце іiі знаходження. Було розподілено відповідальних за кожну ділянку робіт, забезпечення належних консультацій, календарний план робіт. Матеріалом пам'ятника мали використовувати камінь і бронзу, висота обеліска мала скласти 25 м. [9, арк.45-47].

Між тим, 14 липня 1937 р. відповідальному редактору газети «Вісті» надійшов тривожний лист, що повідомляв про негативні факти, що спостерігалися на могилі Шевченка. Далі редактор «Вістей» Ф. Таран інформував 3 цього приводу секретаря ЦК КП(б)У С. Косіора [9, арк.48]. Серед них відмічалося наступне: вкрай незадовільні темпи будівництва музею, дороги до самої могили; погана організація прийому екскурсій; незадовільна робота готелю при заповіднику; антисанітарія та низький рівень обслуговування в їдальні; непрофесійність в організації тематичної «виставки Шевченка»; зрівнялівка в оплаті праці технічного персоналу і наукових працівників; велика кількість скарг від відвідувачів через бруд та грубість персоналу. Від усього в відвідувачів залишалося прикре враження [9, арк.49-51]. В описаних у листі непорядках простежується елементарна непрофесійність, недбальство і якась безпорадна безгосподарність. Скажімо автор констатує, що готель розрахований на 60 місць, а екскурсантів, які залишаються на ніч, часто буває 100-120 осіб в день. Всі, хто не має змоги заплатити 4 крб. за нічліг (а це переважно діти) в приміщення не пускають. Нерідкі випадки, коли діти залишаються на дворі «під голим небом і не сплять ні одної хвилини» розважаючись під гармошку та гітару. Поряд третій рік стоїть і руйнується порожній будинок колишнього гуртожитку художнього інституту на 150 місць. Щоб урятувати будинок від руїни і використовувати для готелю потрібно 10-15 тис. [9, арк.49]. Між тим, чисельність екскурсантів зростала, так лише за червень 1937 р. заповідник відвідало понад 5 тис. чоловік. Прикре враження складала виставка, котра на 95 \% відображала не життя і діяльність Шевченка, а епоху та Миколаївський режим у Росії. Крім того, вражала неохайна подача експонатів виставки, спотворення цитат граматичними помилками та описками [9, арк.50]. В дусі часу автор листа зазначав: «Покидаючи могилу, задаєш собі питання: що тут робиться - чи це крайня межа неохайності, чи може все це [...] діло рук шкідника, який намагається дискредитувати заходи партії i уряду по впорядкуванню могили великого поетареволюціонера» [9, арк.51]. Таким чином, на фоні зростаючого занепаду національних святинь українства та недбалого ставлення до них відповідних радянських працівників, не згасала пам'ять громадськості про Т. Шевченка та зростала увага вищого партійного керівництва до його постаті як знакової ідеологічної фігури в руслі радянської інтернаціональної пропаганди.

Наскільки ретельно влада ставилася до процесу увіковічення знакових національнорадянських постатей можна проілюструвати на процесі зведення пам'ятника Т.Шевченку у Харкові та Києві. Крім художніх діячів до нього були залучені найвищі посадовці держави, котрі визначали не лише розміри кошторису, темпи і засоби будівництва, а мали переважний голос при визначенні художньо-естетичного i, особливо, ідеологічного наповнення монументу.

1 грудня 1935 р. Комітет з будівництва пам'ятника Т.Г. Шевченка в Києві розглянув проект пам'ятника Т.Г. Шевченка в Києві заслуженого діяча мистецтва скульптора М.Г. Манізера та архітектора І.Г. Лангбарда. Пам'ятник являв собою скелю, вершину якої увінчувала фігура поета в глибокій задумі. На нижніх, передньому і боковому виступах скелі розміщувалися дві групи (загальною кількістю 12 фігур): перша зображувала кріпосний гніт миколаївської епохи, друга - селянське повстання. Біля основи пам'ятника розташовувався басейн 3 водою в гранітному обрамленні. Передбачалася 12-ти метрова висота пам'ятника, зробленого із сірого граніту і бронзи, повернутого в бік університету [7, арк.21]. Зробивши низку ідейно-художніх та технічних зауважень, Комітет вирішив за можливе розпочати виконання затверджених частин пам'ятника, одночасно внісши в проект указані зауваження. Начальнику будівництва Т. Рудякову давалося розпорядження 
скласти кошторис і календарний план будівництва з розрахунку його повного завершення навесні 1937 р. [7, арк.21-22]. Загалом, рішенням Комітету робився висновок, що «групи в сюжетному змісті глибоко, динамічно показують під’яремний стан та революційну стихію українського селянства за часів царя Миколи I-го» [7, арк.23]. Вже 6 грудня П.П. Постишев телеграмою із Гагр надсилав партійним колегам своє схвалення проекту пам'ятника [7, арк.25].

Варто наголосити, що до Комітету з будівництва пам'ятника Т.Г. Шевченка в Києві входили представники вищого керівництва УРСР: С.В. Косіор, П.П. Постишев, П.П. Любченко, В.А. Балицький, I.Е. Якір, В.П. Затонський, І.С. Шелехес, А.А. Хвиля [7, арк.21]. Державні та партійні діячі, котрі не мали не лише художньої освіти, а часто вищої освіти загалом. Серед них лише В.Затонський з перервами закінчив фізмат Київського університету і мав перспективи в продовженні фаху, освіта П. Постишева обмежувалася незакінченою початковою школою. Тому не дивно, що службові документи парткерівництва того часу «страждають» численними помилками i безграмотністю. Однак, саме від їх рішення залежала доля художніх та національних цінностей України.

Прикметною рисою сформованої тоталітарної системи була організація реакції народних мас, які вітали державні ініціативи. Так, після прийнятого рішення, на адресу C. Kосіора, П. Постишева і П. Любченка надійшов лист із Владивостока від групи ветеранів Далекого Сходу, котрі вітали ініціативу парткерівництва щодо побудови в столиці України м. Києві пам'ятника Т. Шевченку: «...ми, ветерани далеких куточків нашого Радянського Союзу, відмічаємо, що тільки комуністична партія і радянська влада належним чином вміють так високо цінувати своїх героїв-революціонерів. Нехай знають кати-поміщики і ті, хто з ними, що пролетаріат найкультурнішим чином увічнює пам'ять поета-революціонера кріпосника і що радянська культура досягла високого світового розвитку» [7, арк.27]. Далі вітався факт розбудови Києва - «красивого міста-пам'ятника радянської культури і краси», котре пережило велику руйнацію від ворогів радянської влади в роки громадянської війни і тепер «під керівництвом геніального вождя тов. Сталіна» стане «найкращим містом в світі» [7, арк.28]. Цікавим виглядає вибачення в кінці листа: «прохання вибачити за текст, бо пишемо як вміємо. Навчилися так писати тепер, бо я колишній пастух чужих корів» [7, арк.28]. Насправді, лист написано дуже грамотно і каліграфічно, записки партчиновників КП(б)У часто писалися значно гірше. Подібні листи і телеграми ілюструють добре відпрацьований сценарій, що розігрувався згідно заздалегідь відпрацьованої схеми. Дане привітання несло також ідею інтернаціонального виховання трудящих СРСР, ілюструючи «братерську» радість і торжество перемоги більшовизму в найвіддаленіших «куточках» СРСР.

У 1936 р. на розгляд було представлено 4 варіанти проекту пам'ятника Шевченку в Києві. Комісія в складі Наркома освіти УРСР В.П. Затонського і начальника Українського Управління в справах мистецтв при Раднаркомі УРСР А.А. Хвилі 10 травня 1936 р. давала вказівки щодо необхідних доопрацювань художнього та ідейного плану. У висновку, зокрема, наголошувалося на ідеологічному змісті постаті поета-революціонера Т.Г. Шевченка і покріпаченого українського селянства та на єдності представлених груп, над якими мала височіти постать Шевченка. Комісія вважала можливим приступати авторові до роботи над доопрацюваннями і завершенням проекту пам'ятника [8, арк.4344]. А далі постановою ПБ ЦК КП(б)У від 27.05.36 р. було затверджено висновки В.П. Затонського і А.А. Хвилі по проекту пам'ятника. Нею передбачалося доручити т. Манізеру: 1) провести переробки відповідно до висновків, образно зв'язавши постать Шевченка «як селянського бунтаря» «з нижніми групами поневолених і повсталих селян»; 2) виготовити модель, за зразком якої буде проводитися будівництво пам'ятника. Начальнику будівництва П.М. Рудякову доручалося скласти з Манізером договір та розгорнути на місці будівельні роботи [8, арк.45]. Зауваження щодо проекту скульптору Манізеру було надіслано ще 26 травня, а 27-го вищі посадовці республіки в офіційному листі зазначали, що про нове проектування пам'ятника не може бути й мови, слід внести 
правки і якнайшвидше представити проект на остаточне затвердження, щоб можна було опублікувати в пресі [8, арк.46]. Також 27.05. Манізеру було надіслано висновок Затонського і Хвилі та в супровідному листі за підписами С. Косіора, П. Постишева, П. Любченка підтверджувалися всі попередні рішення щодо внесення ідейних акцентів у пам'ятник та виготовлення його моделі [8, арк.42]. Такий скрупульозний розгляд деталей монументу та підписи вищих посадовців республіки в ході обговорення проекту пам'ятника свідчили про величезну ідеологічну значимість цього процесу, накладали на скульптора колосальну відповідальність i, відповідно, позбавляли творчої ініціативи (особливо, якщо врахувати період розмаху репресій).

5.10 .36 р. Комітет при РНК УСРР по будівництву пам'ятника Т.Г. Шевченка в Києві, розглянувши два нові варіанти проекту, дав цілу низку вказівок щодо посилення художніх, змістових та композиційних рішень проекту. Термін виконання всіх робіт визначався грудень 1937 p. Щодо матеріалу, затверджувався сірий граніт Коростишівських родовищ [8, арк.97].

У листі до С.В. Косіора заслужений діяч мистецтв, скульптор М.Г. Манізер дякував за зауваження, поради і уважне ставлення до своєї роботи. А далі пояснював, що, переглянувши всі варіанти, прийшов до рішення відмовитися від басейну, видозмінити скелю, добавити ще дві фігури для композиційного завершення і посилення враження від епохи. Образ Шевченка в попередніх варіантах пропонували подати в сюртуку чи сорочці. Скульптор вважав найбільш доцільним варіант в сюртуку з опущеною головою і руками 3 пальто за спиною, обличчям повернутим до групи повсталих [8, арк.111-111 зв.].

Зрештою, внаслідок багаторазових втручань політиків, від первісного задуму побудови пам'ятника та образу Кобзаря мало що залишилося. Його відкрили 6 березня 1939 р., спростивши і примітизувавши образ. Було прибрано всі композиційні елементи, що мали символізувати повсталий народ, постать Шевченка височіє на постаменті із похиленою головою, із закладеними за спину руками, на які повішено важкий одяг, що навіює відчуття безвиході. Статичність пам'ятника, його масивність і непорушність пози не узгоджуються $з$ полум'яною вдачею Кобзаря, силою його поезії і мистецької творчості [10].

Таке рішення мало відповідало реалістичному образу Кобзаря, у ньому виключені будь-які національні ознаки постаті. Ще 1904 р., коли в Києві виникла ініціатива спорудження пам'ятника Т.Шевченку, з 1910 до 1914 р. було проведено 4 Міжнародні конкурси на створення проекту пам'ятника, розглянуто близько 160-ти проектів, переважна більшість яких була відкинута саме через невідповідність образу Т.Шевченка [1, с.52-53]. Член Комітету по збудуванню пам'ятника Є. Чикаленко наголошував, що Шевченко має бути обов'язково в національному вбранні: «Не хотять люди зрозуміти, що Шевченко, як народній поет, повинен звертати увагу прохожого народу перше всього народнім убранням, шапкою і кожухом, в якім Шевченко сам любив фотографуватись і в яких уже звик бачити його народ» [5]. Тоді Комітет визнав найбільш відповідним проект італійського скульптора Антоніо Шіортіно, де Кобзаря зображено в українському вбранні [5]. Загалом, довготривалий процес монументалізації пам'яті про Шевченка початку $\mathrm{XX}$ ст. засвідчив поступове витіснення ностальгічно-патріотичного і романтизованого образу Кобзаря XIX ст. і конструювання нового культурного і духовного образу поетапророка, котрий би відповідав формуванню нової української ідентичності [1, с.52].

Радянський образ Шевченка з самого початку не відповідав національним уявленням українців про свого Пророка. Загалом такі моменти мало цікавили партійних керівників, котрі, не шкодуючи коштів на маркування радянського простору, керувалися власними ідейними мотиваціями. Не останню роль відігравала гігантоманія, що проявлялася як імперська цінність в радянській культурі. До речі, в силу домінування ідеологічної складової та мистецької непрофесійності діячів, від яких залежала доля мистецьких пам'яток радянської доби, спотворювалися реалістичні образи не лише національних постатей, а й радянських діячів. Цікавою ілюстрацією цієї думки може слугувати лист 
вдови В. Каменєвої в лютому 1937 р. до Командуючого військами КВО І.Е. Якіра 3 приводу увіковічення пам'яті їі чоловіка. Представлені в газетах два проекти пам'ятника C.С. Каменєва вразили вдову своєю претензійністю і нереалістичнісю. Жінка запитувала, чому Каменєва зображено з гарматою, він ніколи не був артилеристом, хоч будучи головкомом займався всіма видами зброї. Знаючи його людиною скромною і простою, Каменєва вважала зображення чоловіка абсолютно «спотвореним» i просила при можливості вплинути на ситуацію [9, арк.4-5]. Мова в листі йшла про роботи бригади Фрідмана, котрі, до речі, зазнали критики професора Гілярова як невдалі з точки зору художнього вирішення образу (як і інші, представлені на конкурс) [8, арк.115]. У ході вирішення художніх аспектів увіковічення пам'яті героїв нової радянської епохи гору брали ідеологічні виміри і утилітарно-практичне вирішення поставлених завдань, що часто супроводжувалося непрофесійністю і кампанійськими методами.

Ідеологічний аспект в практиці більшовиків 3 вшанування пам'яті Т. Шевченка простежується і в ході відкриття монументальних споруд. Так, до відкриття пам'ятника Кобзарю в Харкові готувалися грунтовно, з метою надання цій події всесоюзного розмаху і відповідного розголосу. 7 березня 1935 р. представники урядової комісії в справі відкриття пам'ятника Т.Г. Шевченка в Харкові, враховуючи стан будівельних робіт, призначили день відкриття на 24 березня 1935 р. На цю подію передбачалося запросити: членів Політбюро ЦК КП(б)У, РНК УСРР і Президії ВУЦВК, представників Ленінградського Обкому та Ленради; від Москви Культпроп ЦК ВКП(б), від Всесоюзної Академії Наук, від Наркомосу РСФРР, персонально Горького; Правління Союзу Радянських Письменників; Оргкомітет художників РСФРР, представника «Правди», «Известий», «Комсомольской правды», представників ВЦРПС, ЦК ЛКСМУ, ВУАН, ВУАМЛІН, ІЧП, газет «Комуніст», «Вісті», «Комсомолець України», «Пролетарська правда», Оргкомітету художників України; Всеукраїнського комітету Спілки радянських письменників України; Оргкомітету композиторів; членів Уряду, членів Уряду Білорусії, Білоруської Академії наук, Білоруського Оргкомітету письменників; Закавказького Уряду і Оргкомітету письменників. А також делегації від Києва, с. Кирилівка (батьківщини Шевченка), областей. Планувалося до Харкова командирувати Затонського, Шелехеса, Ашрафяна, Хвилю, Андрєєва [7, арк.6-7]. Така підготовка свідчила про розмах ідеологічної пропаганди, котра мала показати в загальносоюзному масштабі турботу радянської влади про національних діячів та культуру союзних республік. Далі урядовою комісією було чітко виписано порядок промов від запрошених делегацій, розписано організаційні деталі: навіть кількість трибун для виступаючих (для Уряду, для будівників, для гостей, для дипломатів) i недоречність покладання вінків при відкритті твору мистецтва. У момент відкриття пам'ятника передбачався салют, виконання «Інтернаціоналу» та «Заповіту», загальноміська демонстрація трудящих Харкова та окремих червоноармійських частин без зброї. Встановлювалася загальна кількість гостей, офіційна та неофіційна частина прийому тощо. Указувалося на необхідності за три дні до відкриття пам'ятника дати в пресу рапорт про закінчення його будівництва [7, арк.7-8].

Напередодні церемонії відкриття Секретаріат ЦК КП(б)У розіслав запрошення всім Обкомам, від кожної області запрошувалася делегація з 10-15 осіб із включенням в їх склад робітників, колгоспників, радянської інтелігенції і представників Облвиконкому [7, арк.1]. Від Києва передбачалося 30 чоловік делегації, з представниками с. Кириловка [7, арк.2].

23 березня на адресу трудящих Харкова надійшла привітальна телеграма за підписами С.Косіора та П.Постишева у зв'язку з відкриттям пам'ятника «великому поетуреволюціонеру» Т.Г. Шевченку: «Перемога Харківських більшовиків на фронті національно-культурного будівництва - $\epsilon$ перемогою трудящих Радянської України, кращим доказом перемоги національної політики Леніна-Сталіна» [7, арк.11]. Привітальні телеграми надходили з різних міст України. Вони відбивають уже загально усталену радянську риторику, щодо Шевченка закріпився штамп «поета-революціонера». У 
привітанні від Київського обласного виконкому Рад робітничо-селянських та червоноармійських депутатів та Київської міської Ради робітничих, селянських та червоноармійських депутатів указувалося, що ця подія - наслідок боротьби і єдності всіх трудящих СРСР проти поміщиків і капіталістів, проти українських націоналістів, це наслідок ленінської національної політики. Подія ця засвідчує «величність нашої соціалістичної епохи» [7, арк.9]. Направлялися телеграми 3 місць і в Київ на адресу вищого партійного керівництва України 3 привітанням щодо відкриття пам'ятника «революційному поету» в Харкові [7, арк.15-18].

Загалом весь цей театралізований, чітко організований процес розкриває сутність партійної боротьби за постать Шевченка як символу національного єднання українців. Її красномовно розкриває привітальна телеграма 30-ти тисячного колективу робітників 3 Дніпропетровська, в якій підкреслено велику роль Шевченка як борця минулої епохи, колишнього кріпака, котрий «умів палко любити представників свого класа і люто ненавидити ворогів трудящих». Зміст партійної боротьби з українським націоналізмом та опозицією в самій партії відбито в рядках телеграми: «Контреволюційні українські буржуазно націоналістичні елементи різних гатунків в минулому забризкані кров'ю трудящих України та інші шо прикривалися партквитками та марксовською ідеологією які замовчуючи безперечну революційність Шевченка зробили 3 нього ікону буржуазного куркульського націоналізму. Але всім ворогам які хватаються за Шевченко ми кажемо геть 3 брудними руками. Шевченко вам не віддамо. А що $є$ в ньому такого що нам не підходить на це ми сами відверто вказуємо» [7, арк.16]. Далі в традиційному руслі йшло возвеличення партійної лінії національної політики, схвалення розгрому «великодержавних шовіністів та буржуазних націоналістів», запевнення в відданості більшовизму і готовності до подальшої боротьби проти ворогів радянської держави всіх гатунків, а також впертої роботи в напрямку розбудови радянської української культури, зростання України, як невід'ємної частини СРСР [7, арк.17-18].

Ідеологічна боротьба партійного керівництва за Шевченка, прагнення «не віддати» Кобзаря «буржуазним націоналістам», означала перетворити його постать із символу національного визволення (в роки національно-визвольних змагань портрети Шевченка висіли в усіх національних установах та ледве не в кожній українській хаті) в радянізований образ поета-революціонера, борця проти кріпосного гніту. Мова йшла, фактично, про підміну цінностей, про нівелювання національно-об'єднавчого фактору в процесі української ідентифікації. В певній мірі це вдалося вже в 1930-х рр. До речі, варто указати, що дані підходи в трактуванні постаті Тараса Шевченка залишилися фактично незмінними до кінця існування СРСР. Так, у шкільних підручниках з української літератури за 1987 pp. акцентувалася увага на революційних творах поета, його революційних переконаннях та боротьбі з самодержавством, боротьбі за волю в єдності $з$ «російськими революціонерами-демократами» [4, с.25-27]. Жодної згадки про консолідуючий національний фактор, яким по-суті виступав Т.Шевченко для українства як в роки посиленого національного гноблення, так і національно-визвольної боротьби. Навпаки, підручники доби «перебудови» акцентували увагу на інтернаціональному вшануванні «поета-революціонера» у «вільній сім'ї братніх народів» після «перемоги Жовтня», закріплюючи всі установлені ще 3 1930-х рр. штампи ідейної пропаганди [4, c.27].

Харківське обласне управління НКВС повідомляло про реагування суспільних мас в зв'язку з відкриттям пам'ятника та приїздом в Харків тт. Косіора і Постишева. Серед представників наукових кіл висловлювалися думки, що пам'ятником Шевченку радянські керівники «назавжди заткнули рота націоналістам про те, що українська культура регресує», а «цей пам'ятник остаточно вибиває карти з рук українських націоналістів» [7, арк.19]. Присутність на цій події керівників найвищого рівня складала певну ілюзію демократизму і наближеності вождів до народу. Тому окремі представники селян та робітників, присутніх на врочистостях, відмічали, що керівники вихідці з простих людей, 
тому прийшли подивитися на пам'ятник людині, котра боролася за визволення, показовим для пересічних громадян була видима відсутність охорони [7, арк.20]. Дехто з городян прийшов просто подивитися на «вождів», а декотрі висловлювали обережну критику на адресу керівництва. Показово, що в розмовній практиці населення на адресу керівників України вже установився термін «вожді» [7, арк.20].

Таким чином, протягом 1930-х рp. в Радянській Україні відбувалася монументалізація постаті Т.Шевченка через створення грандіозних пам'ятних скульптур на честь українського Кобзаря. Одночасно, відбувався занепад національної культури, пам'ятних місць, пов'язаних з життям та творчістю поета. Радянізація образу Т.Шевченка стала одним із елементів ідеологічної боротьби з національною ідентичністю українців.

\section{ДЖЕРЕЛА ТА ЛІТЕРАТУРА}

1. Демуз I. Шевченкіана П. Стебницького: громадська ініціатива щодо спорудження пам'ятника поету в Києві на початку XX ст. // Наукові записки з української історії: збірник наукових статей. Переяслав-Хмельницький, 2018. Вип. 44. С.49-59.

2. Із щоденникових записів 1941-1954 pp. (За кн.: О. Довженко. «Україна в огні», К., 1990) // Українське слово. Хрестоматія української літератури та літературної критики ХX ст. (у трьох книгах). Кн. 2. / Упоряд.: В. Яременко, Є. Федоренко; наук. ред. А. Погрібний. Київ: Видавництво «Рось», 1994. С.47-71.

3. Макарчук С.А. Етнографія України. Навчальний посібник. Львів «Світ» 2004. URL: www.ebk.ua/Book/history/makarchuk_eu/part17/170 (дата звернення: 30.05.2019).

4. Падалка Н.I., Сторчак К.М., Цимбалюк В.I. Українська література. Підручник для 6 класу. Затверджений Міністерством освіти УРСР. Видання шістнадцяте. Київ: Радянська школа, 1987. 286 с., іл.

5. Пам'ятник, якому не судилося бути /Прес-Центр. Підготовула Ольга Книжова. URL:http://pres-centr.ck.ua/print/news-4638.html (дата звернення: 30.05.2019).

6. Центральний державний архів громадських об'єднань України (ЦДАГО України), ф.1, оп.20, спр.2691, 76 арк.

7. ЦДАГО України, ф.1, оп.20, спр.6656. 39 арк.

8. ЦДАГО України, ф.1, оп.20, спр.6876. 116 арк.

9. ЦДАГО України, ф.1, оп.20, спр.7103. 69 арк.

10. Шевченку Тарасу пам'ятник. Київ. Енциклопедія. URL: http://wek.kiev.ua/uk/Шевченку_Тарасу_пам'ятник (дата звернення: 30.05.2019).

11. Щекавицьке кладовище // Wikipedia. URL: https://uk.m.wikipedia.org/wiki (дата звернення: 30.05.2019).

\section{REFERENCES}

1. Demuz, I. (2018). Shevchenkiana P. Stebnytskoho: hromadska initsiatyva shchodo sporudzhennia pam'iatnyka poetu v Kyievi na pochatku XX st. [P. Stebnytsky's Shevchenko: a public initiative to build a monument to the poet in Kiev in the early twentieth century]. Naukovi zapysky z ukrainskoi istorii: zbirnyk naukovykh statei - Scientific notes on Ukrainian history: a collection of scientific articles, 44, 49-59. Pereiaslav-Khmelnytskyi [in Ukrainian].

2. Pohribnyi, A. (Ed.). (1994). Iz shchodennykovykh zapysiv 1941-1954 rr. [From the diary entries of 1941-1954 (According to the book: O. Dovzhenko. «Ukraine on fire», K., 1990)]. Ukrainske slovo - Ukrainian word. Kyiv: Vydavnytstvo «Ros», 47-71 [in Ukrainian].

3. Makarchuk, S.A. (2004). Etnohrafiia Ukrainy [Ethnography of Ukraine]. Lviv: «Svit» [in Ukrainian].

4. Padalka, N.I., Storchak, K.M. \& Tsymbaliuk, V.I. (1987). Ukrainska literatura [Ukrainian literature]. Kyiv: Radianska shkola [in Ukrainian].

5. Knyzhova, O. Pamiatnyk, yakomu ne sudylosia buty. pres-centr.ck.ua. Retried from: http://pres-centr.ck.ua/print/news-4638.html [in Ukrainian]. 
6. Tsentralnyi derzhavnyi arkhiv hromadskykh ob'iednan Ukrainy (TsDAHO Ukrainy) [Central State Archives of Public Associations of Ukraine], f.1, op.20, spr.2691, 76 ark. [in Ukrainian].

7. TsDAHO Ukrainy [CDAGO of Ukraine], f.1, op.20, spr.6656. 39 ark. [in Ukrainian].

8. TsDAHO Ukrainy [CDAGO of Ukraine], f.1, op.20, spr.6876. 116 ark. [in Ukrainian].

9. TsDAHO Ukrainy [CDAGO of Ukraine], f.1, op.20, spr.7103. 69 ark. [in Ukrainian].

10. Shevchenku Tarasu pam'iatnyk [Taras Shevchenko monument]. Entsyklopediia. wek.kiev.ua. Retried from: http://wek.kiev.ua/uk/Шевченку_Тарасу_пам'ятник [in Ukrainian].

11. Shchekavytske kladovyshche [Shchekavichy Cemetery]. wikipedia.org. Wikipedia. Retried from: https://uk.m.wikipedia.org/wiki [in Ukrainian].

Одержано 18.04.2019.

УДК 340.136:94(477) «18/19»

\section{Грукач Вікторія,}

кандидат юридичних наук, доцент кафедри загальної історії, правознавства і методик навчання

Lesya612@ukr.net https://orcid.org/0000-0003-4304-4831 Державний вищий навчальний заклад «Переяслав-Хмельницький державний педагогічний університет імені Григорія Сковороди»,

вул. Сухомлинського, 30, м. ПереяславХмельницький, Київська обл., Україна, 08401

\section{DOI https://doi.org/10.31470/2415-3567- 2019-46-85-92}

\section{Hrukach Viktoria,}

Candidate of Jurisprudence, Assistant Professor of General History, Science of Law, Teaching Methods Department

Lesya612@ukr.net https://orcid.org/0000-0003-4304-4831

Pereiaslav-Khmelnytskyi Hryhorii Skovoroda State Pedagogical University,

30, Sukhomlynsky Str., Pereiaslav-Khmelnytskyi, Kyiv region, Ukraine, 08401

\section{ПРАВОВІ ЗАСАДИ ФУНКЦІОНУВАННЯ КИЇВСЬКОГО ГЕНЕРАЛ- ГУБЕРНАТОРСТВА НА ПОЧАТКУ ХХ ст.}

У статті здійснена спроба проаналізувати діяльність київського, волинського, подільського генерал-губернатор, яка мала сприяти подоланню польського впливу на Правобережжі України. На основі комплексного аналізу опублікованих та архівних джерел, історіографічних здобутків розглядаються правові засади створення та подальшої еволюиії інституту генерал-губернаторства у Правобережній Украӥні.

Метою статті є аналіз джерел та висвітлення законодавчих ініціатив, з якими виступали на початку XX cm. генерал-губернатори Південно-Західного краю для зменшення в иььму регіоні польського землеволодіння, щзо мало на той час важливе політичне значення. Констатовано, що Генерал-губернатор як головна посадова особа у генерал-губернаторстві представляв інтереси центральної влади, здійснював контроль за діяльністю всіх адміністративних органів на підвідомчій йому території. У иентрі уваги генерал-губернаторів знаходились політичні проблеми, і саме генерал-губернатори визначали обсяг поширення у краї загальноросійських буржуазних реформ. Керівництво забезпечував за допомогою канцелярії, організаційно-штатна структура якої неодноразово змінювалася. У листопаді 1914 р. Київське генерал-губернаторство було 